\title{
PERATURAN DAERAH ( PERDA ) SYARI'AH DAN PERDA BERNUANSA SYARI'AH DALAM KONTEKS KETATANEGARAAN DI INDONESIA
}

\author{
M Jeffri Arlinandes Chandra \\ Fakultas Hukum Universitas Dehasen Bengkulu \\ Jl. Meranti Raya No 32, Sawah Lebar, Kota Bengkulu \\ Email: Jeffrychandraarlinandes@gmail.com
}

\begin{abstract}
Regional autonomy provides opportunities for each region to make a regional regulation by prioritizing the needs and desires of the people currently needed. Indonesian society is known as its Multicultural so that in determining regional rules it will concern the values, systems, culture, habits, and politics they hold. The existence of multiculturalism has developed a Regional Regulation that reflects its regionalism, for example, based on customs, culture and regional systems, Sharia Regional Regulations in Aceh and Sharia Nuanced Regulations in developing Indonesia. The rise of regional regulations has led to many pros and cons in society and even among politicians. The anti-sharia regulation was launched by the PSI in 3 main party missions. Significant differences between sharia regulations that apply in Aceh with sharia-nuanced local regulations which are mostly born in autonomous regions in Indonesia conclude that whether such regulations are constitutional and whether it is certain that every sharia or sharia-based regional regulation will always be a discriminatory regional regulation and will lead to intolerance for religious people.
\end{abstract}

Keywords: Autonomy, Regional Regulation, Syari'ah.

\begin{abstract}
Abstrak: Otonomi daerah memberikan perluang untuk setiap daerah membuat suatu peraturan daerah dengan mengedepankan kebutuhan dan keinginan masyarakat yang pada saat ini dibutuhkan. Masyarakat indonesia dikenal dengan Multikultulnya sehingga dalam menentukan aturan yang sifatnya kedaerahan akan menyangkut nilai-nilai, sistem, budaya, kebiasaan, dan politik yang mereka anut. Adanya multikulturisme tersebut berkembang Perda yang mencerminkan kedaerahannya misalkan didasari dengan adat istiadat, Budaya dan sistem kedaerahan,Perda Syariah di Aceh dan Perda Bernuansa Syariah di Indonesia yang sedang berkembang. Maraknya bermunculan perda - perda tersebut menimbulkan banyaknya pro dan kontra dalam masyarakat maupun kalangan politisi sekalipun. Gerakan anti perda syariah dicanangkan oleh PSI dalam 3 misi utama partai. Perbedaan yang siknifikan antara perda syariah yang belaku di Aceh dengan perda bernuansa syariah yang banyak lahir di daerah - daerah otonom di Indonesia menimpulkan bahwa apakah perda - perda semacam itu konstitusional dan apakah sudah pasti setiap perda syariah atau bernuansa syariah akan selalu menjadi perda yang diskriminatif dan akan menimbulkan intoleransi bagi umat beragama.
\end{abstract}

Kata Kunci : Otonomi,Perda,Syari'ah. 


\section{Pendahuluan}

Peraturan Daearah (Perda) merupakan wujud dari eksistensi pemerintah daerah bersama - sama dengan DPRD dalam mewujudkan ketenteraman, ketertiban umum, dan pelindungan masyarakat dan sosial masyarakat yang dibuat dalam ketentuan peraturan daerah yang sesuai dengan asas hukum yang tumbuh dan berkembang dalam masyarakat sepanjang tidak bertentangan dengan prinsip Negara Kesatuan Republik Indonesia. Pembentukan Perda harus melalui tahapan perencanaan, penyusunan, pembahasan, penetapan, dan pengundangan yang berpedoman pada ketentuan peraturan perundang - undangan yang terdapat dalam Undang - Undang No 12 tahun 2011 Tentang Pembentukan Peraturan Perundang Undangan agar perda tersebut dapat berlaku dan diberlakukan dalam kehidupan masyarakat. Perda tidak akan ditaati bila bukan merupakan kehendak dari masyarakat yang diakomodir oleh DPRD dalam sistem penyaluran aspirasi masyarakat dan melalui penyusunan rancangan peraturan daerah melalui naskah akademik ( NA ) yang secara filosofis,sosiologis dan yuridis yang dapat dipertanggung jawabkan secara akademik.

Otonomi daerah memberikan perluang untuk setiap daerah membuat suatu peraturan daerah dengan mengedepankan kebutuhan dan keinginan masyarakat yang pada saat ini dibutuhkan. Masyarakat indonesia dikenal dengan Multikultulnya sehingga dalam menentukan aturan yang sifatnya kedaerahan akan menyangkut nilai-nilai, sistem, budaya, kebiasaan, dan politik yang mereka anut. Adanya multikulturisme tersebut berkembang Perda yang mencerminkan kedaerahannya misalkan didasari dengan adat istiadat, Budaya dan sistem kedaerahan yang ada yaitu Perda No 20 Tahun 2008 tentang Peradilan Adat di Papua, Perda No 13 Tahun 2009 tentang Perlindungan Hak - Hak adat dan budaya masyarakat adat kesultanan ternate, dan Perda No 20 tentang 2010 tentang Pembentukan,Susunan organisasi, dan tata kerja majelis adat aceh kota Sabulussalam ${ }^{1}$. Mayoritas agama islam di indonsiapun ikut berperan dalam pembentukan Perda - Perda yang bernuansa ajaran islam ataupun perda yang mereduksi langsung ajaran islam yaitu Perda Syariah misalkan saja Perda Kab. Polewali Mandar no. 14/2006 tentang Gerakan Masyarakat Islam Baca Al-Qur'an, Perda Kab. Bangka No. 4/2006 tentang pengelolaan Zakat, Infaq, dan Shadaqoh, Perda Prov. Gorontalo No. 22/2005 tentang Wajib Baca Tulis Al-Quran bagi siswa yang beragama Islam, Perda Kab. Maros No.15/2005 tentang Gerakan Buta Aksara dan pandai Baca Al-Qur'an dalam Wilayah Kabupaten Maros,Peraturan Daerah Kabupaten Lampung

1 Diambil dari data base Peraturan perundang undangan, http://peraturan.go.id/perda.html, Diakses tanggal 16/11/2018, Pukul 14.05 WIB. 
AL-IMARAH: Jurnal Pemerintahan dan Politik Islam Vol. 3, No. 1, 2018

Selatan No. 4 Tahun 2004 Tentang Larangan Pebuatan Prostitusi, Tuna Susila, dan Perjudian serta pencegahan perbuatan masksiat dalam Wilayah Kabupaten Lampung Selatan kemudian ada juga perda yang disesuaikan dengan ajaran agama kristen ( injil ) yaitu Perda Manokwari Provisi Papua Barat mengenai Penerapan hukum berdasarkan Injil, yang secara spesifik menjelaskan mengenai pelarangan minuman beralkohol dan kegiatan prostitusi, peraturan mengenai busana dan persekutuan, termasuk pelarangan penggunaan dan pemakaian simbol-simbol agama, dan pelarangan pembangunan rumah-rumah ibadat agama lain didekat Gereja pada tahun $2007^{2}$ dan masih banyak lagi perda yang tesebar di pelosok nusantara, .

Maraknya bermunculan perda - perda tersebut menimbulkan banyaknya pro dan kontra dalam masyarakat maupun kalangan politisi sekalipun. Adanya penolakan itu salah satunya oleh partai new comer yang akan menapaki pemilu pertamanya pada tahun 2019 yaitu partai solidaritas indonesia ( PSI ), pada acara ulang tahun ke 4 partai PSI yang bertajuk Festival 11 di Convention Exhibition (ICE) BSD, Pagedangan, Tangerang, Minggu tanggal 11/11/2018, pada pidato dengan judul "Muda Menangkan Indonesia" ketua umum PSI yaitu Grace Natalie Louisa menyampaikan pada pidatonya bahwa PSI mempunyai 3 Misi

\footnotetext{
${ }^{2}$ https://id.wikipedia.org/wiki/Daftar_peraturan_da erah_di_Indonesia_berlandaskan_hukum_agama, Diakses pada tanggal 16/11/2018, 14.23 WIB.
}

utama yaitu salah satunya PSI akan mencegah lahirnya ketidakadilan, diskriminasi dan seluruh tindakan intoleransi di negeri ini, yaitu dengan cara PSI tidak akan mendukung perda - perda - perda injil atau perda - perda syariah karena tidak boleh ada lagi penutupan rumah rumah ibadah secara paksa ${ }^{3}$.

Dengan demikian Pro dan Kontra perda perda tersebutlah yang terjadi masyarakat maka perlu adanya pembahasan yang mendasar apakah suatu Perda bernuansa syariah maupun perda syariah tersebut akan menimbulkan tindakan - tindakan intoleransi, ketidakadilan, dan diskriminasi atau dengan kata lain bertentantang dengan UUD NKRI 1945. maka dari itu penulis akan membahas mengenai apakah perda syariah/perda yang benuansa syariah dan perda injil bertentangan dengan konstitusi dan apa saja yang menjadi muatan suatu perda tersebut.

\section{Pembahasan}

\section{a. Otonomi Daerah dan Kewenangan} Pembentukan Peraturan daerah

\section{( Perda )}

Otonomi atau Autonomy berasal dari dua suku kata bahasa Yunani, yaitu: "autos" yang berarti "sendiri atau self" dan "nomous" yang berarti "hukum atau peraturan" yang berarti: memberi aturan sendiri, pemerintahan sendiri; atau hak

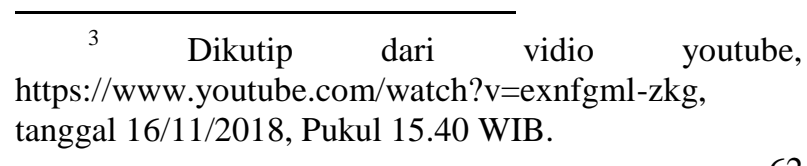


untuk memerintah sendiri ${ }^{4}$. Secara etimologi, otonomi adalah kemampuan untuk membuat keputusan sendiri tentang apa yang hendak dilakukan terlepas dari pengaruh orang lain, atau mengungkapkan apa yang ingin diperbuat ${ }^{5}$.

Dalam Kamus Ilmiah Populer kata "Otonom" berarti "badan" (Daerah) yang mendapat hak otonomi. Sementara "Otonomi" sendiri mengandung arti mengurus diri (rumah tangga) sendiri; pelaksanaan pemerintahan sendiri ${ }^{6}$. Dalam literatur Belanda "Otonomi" searti dengan Zelfregering yang berarti pemerintahan sendiri, yang oleh Van Vollenhoven di bagi menjadi Zelfwetgeving (membuat undang-undang sendiri), dan Zelfuitvoering (melaksanakan sendiri), Zelfrechtspraak (mengadili sendiri), dan Zelfpolitie (memerintah sendiri).

Otonomi Daerah berarti self government atau condition of living under one "s own lows. Artinya otonomi daerah adalah daerah yang memiliki legal self sufficiency yang bersifat self government

\footnotetext{
${ }^{4}$ Liat William L. Reece, Dictionary of Philosophy and Religion: Eastern and Western Though, Exponded Edition, New York: Humanity Books, 1996), h. 54, Kamus Besar Bahasa Indonesia, Cet. I (Jakarta: Balai Pustakan, 1998), h. 58.

5 Baca Jhon Sinclair (Ed), Collins COBUIL English Language Dictionary, Cet. 6, (London: Collins, 1990), h. 85

6 Pius A partanto dan M. Dahlan Al-barry, Kamus Ilmiah Populer, (Surabaya: Arkola, 1994). 63
}

yang diatur dan diurus oleh own laws ${ }^{7}$, sehingga dapat disimpulkan bahwa otonomi daerah adalah Hak wewenang dan kewajiban daerah untuk mengatur dan mengurus rumah tangganya sendiri sesuai dengan peraturan perundang-undangan yang berlaku.

Otonomi Daerah merupakan pelimpahan kewenangan yang dilakukan oleh pemerintah pusat, sesuai dengan UU Nomor 23 tahun 2014 Tentang Pemerintahan Daerah. Klasifisikasi urusan pemerintahan dibagi menjadi urusan pemerintahan absolut, Konkuren, dan urusan pemerintahan umum. Urusan pemerintahan absolut merupakan sepenunya kewenangan pemerintah pusat ${ }^{8}$, Urusan Konkuren merupakan urusan pemerintahan yang dibagi antara pemerintah Pusat dan daerah provinsi dan daerah kabupaten/kota sehingga urusan konkuren yang diberikan ke daerah menjadi dasar pelaksanaan otonomi daerah ${ }^{9}$, dan pemerintahan pemerintahan umum merupakan kewenangan presiden sebagai kepala pemerintahan ${ }^{10}$. Kewenangan konkurenlah yang membuat daerah yang memiliki legal self sufficiency yang bersifat

7 Sarundajang, Arus Balik Kekuasaan Pusat ke Daerah, (Jakarta: Pustaka Sinar Harapan, 1999), h.2.

${ }^{8}$ Pasal 9 ayat (2) Undang - Undang Pemerintah Daerah.

${ }^{9}$ Pasal 9 ayat ( 3 ) dan (4) Undang - Undang Pemerintahan Daerah.

10 Pasal 9 ayat ( 5 ) Undang - Undang Pemerintahan Daerah. 
self government yang diatur dan diurus oleh pemerintah setempat ${ }^{11}$, karena itu otonomi lebih menitikberatkan aspirasi masyarakat setempat daripada kondisi yang berbeda di daerah.

Untuk menjalankan otonomi daerah dan tugas pembantuan maka pemerintah daerah dapat membuat Peraturan daerah ( PERDA ) untuk membantu menjalankan kewenangan konkuren tersebut. Perda adalah semua peraturan yang dibuat oleh pemerintah setempat untuk melaksanakan peraturan-peraturan lain yang lebih tinggi derajatnya $^{12}$. PERDA dibuat oleh Kepala daerah bersama - sama dengan DPRD sesuai dengan tingkatannya, PERDA Provinsi dibuat oleh Gubernur bersama dengan DPRD Provinsi dan PERDA Kabupaten/Kota dibuat oleh Bupati/walikota bersama - sama dengan DPRD kabupaten/Kota.

Menurut UU No 23 Tahun 2014 tentang pemerintahan daerah pada pasal 65 ayat (1) dan (2) menyebutkan bahwa kepala daerah mempunyai tugas yaitu :

1. Memimpin pelaksanaan Urusan Pemerintahan yang menjadi kewenangan Daerah berdasarkan ketentuan peraturan

11 Syaukani HR., Menatap Harapan Masa Depan Otonomi Daerah, Kutai, Lembaga Pengembangan Pembedayaan Kutai, h 147

12 Bagir Manan, Menyongvong Fajar Otonomi Daerah, PSH FH UlI, Yogyakarta, 2002, h. 136. perundang-undangan dan kebijakan yang ditetapkan bersama DPRD;

2. Memelihara ketenteraman dan ketertiban masyarakat;

3. Menyusun dan mengajukan rancangan Perda tentang RPJPD dan rancangan Perda tentang RPJMD kepada DPRD untuk dibahas bersama DPRD, serta menyusun dan menetapkan RKPD;

4. Menyusun dan mengajukan rancangan Perda tentang APBD, rancangan Perda tentang perubahan APBD, dan rancangan Perda tentang pertanggungjawaban pelaksanaan APBD kepada DPRD untuk dibahas bersama;

5. Mewakili Daerahnya di dalam dan di luar pengadilan, dan dapat menunjuk kuasa hukum untuk mewakilinya sesuai dengan ketentuan peraturan perundangundangan;

6. Mengusulkan pengangkatan wakil kepala daerah; dan

7. Melaksanakan tugas lain sesuai dengan ketentuan

peraturan perundang-undangan.

Kemudian dalam menjalankan tugasnya kepala daerah mempunyai kewenangan :

1. Mengajukan rancangan Perda; 
Menetapkan Perda yang telah mendapat persetujuan bersama DPRD;

2. Menetapkan Perkada dan keputusan kepala daerah;

3. Mengambil tindakan tertentu dalam keadaan mendesak yang sangat dibutuhkan oleh Daerah dan/atau masyarakat;

4. Melaksanakan wewenang lain sesuai dengan ketentuan peraturan perundang-undangan

Suatu Perda baik Perda Provinsi maupun Perda Kabupaten/Kota haruslah dibentuk secara bersama - sama dengan DPRD dengan sesuai tingkatannya. DPRD dalam menjalankan tugasnya yaitu :

1. Membentukan Perda;

2. Anggaran; dan

3. Pengawasan.

Untuk menjalankan fungsinya tersebut DPRD baik provinsi maupun kabupaten/kota mempunyai tugas dan wewenang sesuai dengan pasal 101 untuk tugas dan kewenangan provinsi dan pasal 154 uu Pemeritahan Daerah untuk tugas dan kewenangan Kabupaten/Kota :

1. Membentuk Perda Provinsi maupun kabupaten/kota bersama gubernur dan atau walikota/bupati;

2. Membahas dan memberikan persetujuan Rancangan Perda Provinsi maupun kabupaten/kota tentang APBD Provinsi maupun kabupaten/kota yang diajukan oleh gubernur atau ke walikota/bupati;

3. Melaksanakan pengawasan terhadap pelaksanaan Perda Provinsi maupun kabupaten/kota dan APBD provinsi maupun kabupaten/kota;

4. Memilih gubernur atau walikota/bupati;

5. Mengusulkan pengangkatan dan pemberhentian Bupati/Walikota ke Menteri melalui Gubenur,atau memberhentikan Gubernur kepada Presiden melalui Menteri untuk mendapatkan pengesahan pengangkatan dan pemberhentian;

6. Memberikan pendapat dan pertimbangan kepada Pemerintah Daerah provinsi maupun kabupaten/kota terhadap rencana perjanjian internasional di Daerah provinsi maupun kabupaten/kota;

7. Memberikan persetujuan terhadap rencana kerja sama internasional yang dilakukan oleh Pemerintah Daerah provinsi maupun kabupaten/kota;

8. Meminta laporan keterangan pertanggungjawaban gubernur atau Bupati/Walikota dalam penyelenggaraan Pemerintahan Daerah provinsi maupun kabupaten/kota;

9. Memberikan persetujuan terhadap rencana kerja sama dengan Daerah lain atau 
dengan pihak ketiga yang membebani masyarakat dan Daerah provinsi maupun kabupaten/kota; dan

10. Melaksanakan tugas dan wewenang lain yang diatur dalam ketentuan peraturan perundang-undangan.

Peraturan daerah merupakan suatu bentuk kebijakan yang dilakukan secara bersama - sama antara pemimpin daerah ( Gubernur/Walikota/Bupati ) dengan DPRD Provinsi/Kota/Kabupaten.

Peraturan tersebut haruslah dibuat berdasarkan kehendak dari masyarakat sebagai bentuk legitimasi hukum mengenai kebutuhan yang dihadapi masyarakat. Idealnya bahwa untuk menghasilkan produk peraturan daerah yang baik dan dapat berlaku efektif, maka segenap komponen masyarakat harus dilibatkan, olehnya perangkat di daerah utamanya bagian hukum harus lebih pro aktif dalam menyerap aspirasi masyarakat untuk kemudian dituangkan dalam rancangan peraturan daerah yang akan diatur.

Pembuatan suatu PERDA bukan mudah akan tetapi harus melalui tahapan - tahapan yang telah diatur dalam UU P3, yaitu melalui perencanaan, penyusunan,pembahasan, pengesahan atau penetapan, dan pengundangan. Dalam tahapan penyusunan RAPERDA
( Rancangan Peraturan Daerah ) harus melalui uji dan pelitian lapangan yang akan merenkomendasikan bahwa apakah suatu PERDA tersebut harus dibuat,dibuat dalam peraturan lain atau tidak perlu diatur dalam PERDA yaitu melalui Naskah Akademik.

Naskah Akademik ( NA ), yaitu naskah hasil penelitian atau pengkajian hukum dan hasil penelitian lainnya terhadap suatu masalah tertentu yang dapat dipertanggungjawabkan secara ilmiah mengenai pengaturan masalah tersebut dalam suatu Rancangan Undang-Undang, Rancangan Peraturan Daerah Provinsi, atau Rancangan Peraturan Daerah Kabupaten/Kota sebagai solusi terhadap permasalahan dan kebutuhan hukum masyarakat ( Pasal 1 No 11 UU P3 ).

Isi naskah akademik tersebut mencakup :

1. Landasan Filosofis (filisofische groundslag) merupakan pertimbangan atau alasan yang menggambarkan bahwa peraturan yang dibentuk mempertimbangkan pandangan hidup, kesadaran, dan cita Hukum ,

2. Landasan Sosiologis (sociologische groundslag) merupakan pertimbangan atau alasan yang menggambarkan bahwa peraturan yang dibentuk untuk 
memenuhi kebutuhan masyarakat dalam berbagai aspek

3. Landasan yuridis (rechtground) merupakan pertimbangan atau alasan yang menggambarkan bahwa peraturan yang dibentuk untuk mengatasi permasalahan hukum atau mengisi kekosongan hukum dengan mempertimbangkan aturan yang telah ada. Landasan yuridis terbagi menjadi 2 yaitu $^{13}$ :

a) Segi Formal yaitu ketentuan hukum yang memberikan wewenang kepada badan pembentuknya.

b) Segi material adalah ketentuan-ketentuan hukum tentang masalah atau persoalan apa yang harus diatur.

Maka hasil penelitian tersebutlah yang akan merekomendasikan apakah untuk menyelesaikan suatu permasalahan yang terjadi di masyarakat haruskah dibuat dalam peraturan daerah ( Perda ), dibuat dalam peraturan lain ( PerGub,PerBub,Perwal dll ) atau tidak perlu dibuat peraturan sehingga masyarakat akan menyelesaikan permasalahan itu sendiri.

\section{b. Materi Muatan dalam Peraturan Daerah ( PERDA ).}

Pembentukan Perda haruslah sesuai dengan Materi muatan Perda. Materi muatan dalam suatu perda merupakan seluruh materi dalam rangka menyelengarakan otonomi daerah dalam rangka menyelengarakan otonomi daerah dan tugas pembantuan, selain itu Perda dapat memuat materi muatan lokal sesuai dengan ketentuan peraturan perundang-undangan dan juga asas hukum yang tumbuh dan berkembang dalam masyarakat sepanjang tidak bertentangan dengan prinsip Negara Kesatuan Republik Indonesia $^{14}$. Oleh karena itu materi Perda secara umum memuat antara lain:

1. Hal-hal yang berkaitan dengan rumah tangga daerah dan hal - hal yang berkaitan dengan organisasi pemerintah daerah;

2. Hal-hal yang berkaitan dengan tugas dan pembantuan (Mendebewindl) dengan demikian Perda merupakan produk hukum dari pemerintah daerah dalam rangka melaksanakan otonomi daerah, yaitu melaksanakan hak dan kewenangan untuk mengatur dan mengurus urusan rumah tangga sendiri sekaligus juga Perda

\footnotetext{
${ }^{14}$ Pasal 236 ayat (3) dan (4) dan Pasal 237 ayat (1) UU Pemerintahan Daerah.
}

13 Amiroeddin Syarif, Perundang-undangan,Dasar, Jenis dan Teknk Membuatnya, Bina Aksara, Jakarta, 1987, h.. 91-94. 67 
AL-IMARAH: Jurnal Pemerintahan dan Politik Islam Vol. 3, No. 1, 2018

$\begin{array}{lrr}\text { merupakan legalitas } & \text { untuk } \\ \text { mendukung Pemerintah } & \text { Provinsi } \\ \text { maupun kabupaten/kota } & \text { sebagai } \\ \text { daerah otonom }{ }^{15} \text {. }\end{array}$

Hukum merupakan suatu alat untuk memelihara ketertibah (order) dalam suatu masyarakat. Karena fungsi hukum pada dasamya adalah memelihara dan mempertahankan yang telah tercapai. Perkembangan hukum sebagai alat kontrol masyarakat ( a tool of social engineering) yang artinya meningkatkan ketertiban dan kepastian hukum dalam masyarakat.

Untuk mewujudkan hal tersebut Arif Sidharta menarik kesimpulan asas dalam hukum Pancasila yaitu ${ }^{16}$ :

a. Asas semangat kerukunan, yaitu ketertiban,keteraturan yang bersuasana ketenteraman batin,kesenangan bergaul diantara bersamanya, keramahan dan kesejahteraan (baik materil maupun spiritual).

b. Asas Kepatutan, Yaitu tentang tata cara menyelenggarakan hubungan antar warga masyarakat yang didalamnya para warga masyarakat diharuskan untuk berperilaku dalam kepatutan yang sesuai dengan kenyataan-kenyataan social.

15 Rosjidi Ranggawidjaja, Pengantar Ilmu Perundang-undangan Indonesia, Penerbit Mandar Maju, Bandung, 1998, h. 23.

16 Rudi M Rizky, Filsafat Hukum Pancasila, h. 16
c. Asas Keselarasan, Yaitu terselenggaranya harmoni dalam kehidupan bermasyarakat.

Asas - asas diatas haruslah terecermin dalam membuat peraturan perundang undangan baik undang - undang maupun Peraturan daerah.

Selain Asas dalam hukum pancasila maka harus memperhatikan juga asas hukum, asas hukum merupakan tiang utama bagi setiap pembentukan undang-undang. Menurut Satjipto Rahardjo, asas hukum dapat diartikan sebagai suatu hal yang dianggap oleh masyarakat hukum yang bersangkutan sebagai basic truth atau kebenaran asasi ${ }^{17}$. Menurut Padmo Wahjono Asas hukum dibagi atas dua hal $^{18}$ :

1. Asas pembentukan perundang-undangan.

2. Asas materi hukum. Asas hukum yang menyangkut substansi peraturan perundang-undangan ialah azas hukum yang berkaitan erat dengan materi muatan suatu peraturan perundang-undangan yang akan dirancang.Tentang jenis asas

17 Satjipto Rahardjo, Peranan dan Kedudukan Asas-Asas Hukum dalam Kerangka Hukum Nasional, (Makalah) FH, Universitas Indonesia, 2000, h. 10.

18 Padmo Wahyono dalam Ronny Sautma Hotma Bako, Pengantar Pembentukan UndangUndang RI, PT. Citra Aditya Bakti, Bandung, 1991, h.. 45. 
perundang-undangan ini Amiroeddin

Syarif mengemukakan 5 asas yaitu ${ }^{19}$ :

a) Asas tingkat hirarki; yaitu suatu perundang-undangan isinya tidak boleh bertentangan dengan inti perundangundangan yang lebih tinggi tingkatan atau derajatnya.

b) Undang-undang tidak diganggu gugat; asas ini berkaitan dengan hak menguji perundang-undangan (Foetsingrecht) hak menguji secara material dan hal menguji secara formal.

c) Undang-undang yang bersifat khusus menyampingkan undangundang yang bersifat umum (lex specialis derogat lex generalis); undang-undang yang umum adalah yang mengatur persoalanpersoalan pokok tersebut tetapi pengaturannya secara khusus menyimpang dan ketentuanketentuan undang-undang yang umum tersebut.

d) Undang-undang tidak berlaku surut;

e) Undang-undang yang barn menyampingkan undang-undang yang lama (lex posteriori derogat lex priori); apabila ada suatu masalah diatur dalam suatu

19 Sunaryati Hartono, dalam Ronny Sautma Hotma Bako.... undang-undang (lama), diatur pula dalam undang-undang yang baru, maka ketentuan undang-undang yang baru berlaku.

Asas - asas tersebut hasil diperhatikan dalam membentuk suatu pertauran perundang undangan kemudian dengan adanya tata urutan peraturan perundang-undangan yang diatur dalam UU Pembentukan Peraturan Perundang-Undangan yang menjadikan peraturan perundang - undngan itu menjadi suatu sistem peraturan perundang - undangan maka memiliki konsekuensi sebagai berikut ${ }^{20}$ :

1. Setiap produk peraturan perundang-undangan hanya dapat dikeluarkan oleh yang berwenang.

2. Sejenis peraturan perundang-undangan hanya dapat memuat materi sesuai dengan tingkatan jenis peraturan perundang-undangannya

3. Peraturan perundang-undangan yang lebih rendah tidak boleh bertentangan dengan peraturan perundangundangan yang lebih tinggi.

4. Dikeluarkannya setiap produk peraturan perundang-undangan harus diarahkan dalam rangka menuju terwujudnya masyarakat sebagaimana telah diamanatkan dalam tujuan negara.

20 Dahlan Thaib, Tata Cara Mengaplikasikan Peraturan Perundangundangan, (Makalah) FH-Ulf. Yogyakarta, 2003, h.. 24. 
AL-IMARAH: Jurnal Pemerintahan dan Politik Islam Vol. 3, No. 1, 2018

5. Apabila terdapat suatu produk peraturan perundangundangan yang tidak tact asas dalam sistem peraturan perundang-undangan maka akan berakibat rusaknya suatu sistem peraturan perundang-undangan itu sendiri.

Maka dapat disimpulkan bahwa dalam pembuatan peraturan perundang- undangan baik, Undang - Undang, Peraturan Pemerintah,Peraturan Presiden,Peraturan Daerah Provinsi maupun Peraturan daerah Kabupaten ataupun kota haruslah sesuai dengan pembentukan peraturan perundangan - undangan yang benar, baik benar cara membuatnya maupun benar siapa yang berwenang membuatnya. Materi dalam suatu perdapun harus sesuai dengan asas - asas norma hukum yang berlaku di Indonesia sehingga setiap perda tidak boleh bertentanggan dengan peraturan yang lebih tinggi hierarkinya.

\section{c) Perda Syariah dan Perda Bernuansa Syariah di Indonesia}

Secara etimologis (bahasa), syariah berarti "jalan ke tempat pengairan” atau “jalan yang harus diikuti” atau tempat lalu air di sungai" ${ }^{21}$. Secara terminologis (istilah), syariah menurut Syaikh Mahmud Syaltut, mengandung arti hukum-hukum dan tata aturan yang Allah syariatkan bagi hambanya untuk diikuti. Menurut Faruq

21 Prof. Dr. H. Amir Syarifudin, Ushul Fiqh Jilid I, (Jakarta: Logos Wacana Ilmu, 1997), Cet. I, h. 1
Nabhan secara istilah syariah berarti "segala sesuatu yang disyariatkan Allah kepada hamba-hambanya. Sedangkan menurut Manna ${ }^{e e}$ al-Qathan, syariah berarti "segala ketentuan Allah yang disyariatkan bagi hamba-hambanya, baik menyangkut akidah, ibadah, akhlak maupun muamalah ${ }^{22}$.

Syari'ah disebut juga sebagai hukum amaliah, pengkhususan ini dimaksudkan karena agama pada dasarnya adalah satu dan berlaku secara universal, sedangkan syariah berlaku untuk masing-masing umat yang berbeda dengan umat sebelumnya. Dengan demikian kata syariah lebih khusus dari agama ${ }^{23}$. Pembahasan tentang syariah sesungguhnya berbicara tentang nilai, norma, hukum, aturan atau yang lebih tepat disebut ajaran atau doktrin Islam yang bersumber dari al-Quran dan Hadits Nabi, sejarah Muhammad SAW, dan sejarah Islam secara keseluruhan. Karena ajaran atau doktrin yang dibawa oleh Nabi Muhammad SAW ini masih membutuhkan penjabaran yang lebih luas, maka oleh para mufasir dilakukan penafsiran terhadap teks kitab suci untuk menangkap makna yang terkandung di

22 Dr. H. Fathurrahman Djamil, M.A, Filsafat Hukum Islam; Bagian Pertama, (Jakarta: Logos Wacana Ilmu), Cet. I, h. 7

${ }^{23}$ Ibid, h. 2. 
dalamnya agar dapat dimengerti dan dipahami oleh umat Islam.

\section{1) Peraturan daerah Syari'ah}

\section{( Qanun ) di Aceh}

Fakta sejarah perjuangan

konstitusional dengan diberlakuan syari'at Islam di Aceh, karena di undangkannya Undang-Undang Republik Indonesia Nomor 44 Tahun 1999, tentang keistimewaan Aceh hingga lahirnya Undang-Undang No. 11 Tahun 2006 tentang Pemerintahan Aceh, yang menegaskan dan memperkuat pelaksanaan Syari'at Islam secara Kaffah ( Keseluruhan ) melalui pembentukan norma antara pemerintah aceh dengan Dewan Perwakilan Rakyat Aceh ( DPRA) dalam menyusun qanun aceh yang melaksanakan syariat islam.

Sesuai dengan sistem yang dianut oleh indonesia yaitu sistem hukum sipil tertulis atau civil law system ${ }^{24}$ maka sistem hukum ini menuntur suatu peraturan yang dapat diterima sebagai hukum hanyalah yang telah ditentukan dan ditetapkan secara positif oleh negara. Hukum hanya berlaku karena hukum mendapat bentuk positifnya dari instansi

${ }^{24}$ Marzuki Wahid, Rumadi, Fiqh Mazhab Negara, Kritik Terhadap Politik Hukum Islam di Indonesia,(Yogyakarta: LKIS, 2001), h. 2. yang berwenang (negara) ${ }^{25}$. Dalam konteks Aceh, hukum jinayat sebagai sub sistem hukum nasional hanya dapat berlaku setelah melalui proses legislasi dan berubah wujud dalam bentuk Qanun ( Perda ) Aceh, sehingga menjadi hukum positif berdasarkan peraturan perundang-undangan yang berlaku ${ }^{26}$. Qanun aceh mengatur mengenai 2 hal yaitu Qanun mengenai Pemerintahan Aceh dan Qanun yang mengatur kehidupan masyarakat aceh.

Pemberlakukan hukum jinayah dalam masyarakat aceh tertuang dalam Qanun Aceh Nomor 7 Tahun 2013 Tentang Hukum Acara Jinayat. Hukum acara Jinayah ini berisikan tentang mengenai bagaiman setiap qanun atau aturan aturan dalam masyratakat aeceh dapat ditegakan yang sama halnya dengan KUHAP akan tetapi berbeda paradigma. Paradigma yang digunakan pada hukum acara jinayah adalah paradigma hukum syari'ah yang bersifat akomodatif terhadap materi KUHAP.

25 Aliran hukum positif mengartikan hukum sebagai a command of the lawgiver (perintah dari pembentuk undang-undang atau penguasa, yaitu suatu perintah dari mereka yang memegang kekuasaan tertinggi atau yang memegang kedaulatan. Astim Riyamto, Filsafat Hukum, (Bandung: YAPEMDO, 2010), h. 503.

${ }^{26}$ Lihat Qanun Aceh Nomor 7 tahun 2013 tentang Hukum Jinayat, kata pengantar Prof. Dr. H Syahrizal Abbas,MA, h. 9. 
Perbedaan antara hukum acara jinayat dengan KUHAP yaitu memiliki asas yang berbeda, salah satunya adalah asas pembelajaran kepada masyarakat ( tadabbur ), adalah asas yang mana semua proses peradilan, mulai dari penangkapan, sampai kepada pelaksanaan 'uqubat harus mengandung unsur pendidikan, agar masyarakat mematuhi hukum, mengetahui proses penegakan hukum dan perlindungan masyarakat, karena tujuan dari menghukum orang adalah untuk mendidik, memberikan pelajaran dan menumbuhkan kesadaran hukum $^{27}$.

Asas - asas hukum acara jinayah yang diadopsi dari KUHAP yaitu antara lain asas legalitas, keadilan dan keseimbangan, perlindungan HAM, Praduga tak bersalah ( presumption of innocent ), ganti kerugian dan rehabilitasi, peradilan yang menyeluruh, sederhana cepat dan biaya ringan, peradilan terbuka untuk umum, kekuasaan kehakiman yang sah, mandiri dan tetap dan asas bantuan hukum bagi terdakwa $^{28}$.

Selain itu hukum acara jinayah ini bukan hanya mengatur masyarakat islam di Aceh akan tetapi juga mengatur masyarakat non islam di Aceh dengan asas penundukan diri, sehingga pelaku jarimah yang beragama islam dapat memilih dan menundukan diri pada qanun ini, dan akan diperiksa dan diadili oleh mahkamah Syar'iyah. Penundukan diri ini merupakan hal yang baru pada hukum pidana nasional indonesia yang sebelumnya tidak mengenal adanya pilihan hukum ( choice of law ) dan penundukan diri ${ }^{29}$.

Keunikan daerah istimewa aceh ini yang diakui oleh bangsa indonesia secara konstitusional yang kemudian tuangkan dalam UU tentang Keistimewaan aceh dan UU Pemerintahan Aceh. Secara konstitusional bahwa semua produk hukum yang dilahirkan di aceh harus dihormati dan diakui karena merupakan kesepakatan bangsa untuk menjalankan amanat pasal 18B UUD 1945 yang memasukan aceh dalam salah satu daerah istimewa yang ada di Indonesia. Maka secara hukum formil yang belaku di Indonesia bahwa qanun dan aturan aturan di Aceh adalah Konstitusional sepanjang tidak bertentangan dengan Peraturan yang ada diatasnya.

\footnotetext{
27 Ibid, h. 10.

${ }^{28}$ Ibid, h. 11.
}

29 Ibid, h. 19 
Adapun Qanun - Qanun yang berlaku di Aceh antara lain ${ }^{30}$ :

\section{No Qanun yang Berlaku di Aceh}

1 Qanun Nomor 11 Tahun 2002 tentang pelaksanaan syariat islam bidang Aqidah, Ibadah dan Syir'ar Islam.

2 Qanun Nomor 12 Tahun 2003 tentang larangan Khamar (minuman keras), pelaku yang mengkonsumsi khamar akan dijatuhi hukuman cambuk 40 kali. Hakim tidak di beri izin untuk memilih (besar kecil atau tinggi rendah) hukuman. Bagi yang memproduksi khamar dijatuhi hukuman ta'zir berupa kurungan paling lama satu tahun, paling sedikit 3 bulan dan denda paling banyak Rp 75.000.000 (tujuh puluh lima juta) dan paling sedikit Rp 25.000.000 (dua puluh lima juta rupiah).

\begin{tabular}{ll}
\hline 3 & Qanun Nomor 13 Tahun 2003 \\
& tentang larangan Maysir \\
& (perjudian). \\
& Qanun Nomor 14 Tahun 2003 \\
& tentang larangan Khalwat \\
& (perbuatan mesum). \\
& Qanun Nomor 7 Tahun 2004
\end{tabular}

\footnotetext{
${ }^{30}$ Dihimpun dari berbagai sumber.
}

\begin{tabular}{|c|c|}
\hline & tentang pengelolaan Zakat \\
\hline 6 & $\begin{array}{lll}\text { Qanun Nomor } 8 \text { Tahun } 2016 \\
\text { tentang Sistem Jaminan Produk } \\
\text { Halal }\end{array}$ \\
\hline 7 & $\begin{array}{lrr}\text { Qanun Nomor } 8 \text { tahun } & 2015 \\
\text { tentang } & \text { pembinaan } & \text { dan } \\
\text { perlindungan aqidah, dll. } & \end{array}$ \\
\hline
\end{tabular}

\section{2) Perda Bernuansa Syariah di Indonesia}

Sesuai dengan sensus penduduk tahun 2010 bahwa pemeluk agama islam di Indonesia mencapai $87,18 \%$ atau 237.641.326 penduduk Indonesia adalah pemeluk Islam, $\quad 6,96 \%$ Protestan, 2,9\% Katolik, $\quad 1,69 \%$ Hindu, 0,72\% Buddha, dan sisanya merupakan agama lainya atau tidak menjawab ${ }^{31}$. Adanya dominasi agama tersebut menyebabkan nilai - nilai yang dianggap baik oleh suatu agama di implemtasikan kedalam hukum formal agar dapat mengatur kehidupan bermasyarakat berbangsa dan bernegara.

Menurut Dr. Buehler dosen perbandingan politik di SOAS menyatakan bahwa Peraturan daerah syariah telah banyak dibentuk oleh Kepala daerah bersama - sama dengan DPRD

${ }^{31} \mathrm{https} / / /$ id.wikipedia.org/wiki/Agama_di_Indonesi a, diambil Sensus Penduduk 2010. Jakarta, Indonesia: Badan Pusat Statistik, diakses tanggal 21 November 2018, 22.47 WIB. 
AL-IMARAH: Jurnal Pemerintahan dan Politik Islam Vol. 3, No. 1, 2018

sejak mulai tahun 1998 sampai sekarang paling tidak sudah ada 443 Perda Syariah yang diterapkan di berbagai wilayah di Indonesia $^{32}$.

Ada perbedaan yang siknifikan antara perda syariah yang belaku di Aceh dengan perda bernuansa syariah yang banyak lahir di daerah - daerah otonom di Indonesia yaitu terletak pada norma yang digunakan, bila perda syariah memang mengunakan norma agama sebagai landasannya dan diakomodir kedalam bentuk perda secara keseluruhan baik hukumnya maupun hukumannya ( Kaffah/keseluruhan ) sedangkan Perda Bernuansa Syariah normanya harmonis/tidak kontra produktif dengan norma syariah akan tetapi juga menjunjung tinggi norma - norma hukum yang diberlakukan agar suatu umat tertentu tidak merasa terganggu atas kehadiran perda tersebut melainkan dapat hidup bersama dan berdampingan.

Perda bernuansa syariah yang ada di Indonesia antara lain :

\section{No Perda Bernuansa Syariah}

1 Perda Kabupaten Bengkulu Tengah No 5 Tahun 2014 Tentang wajib Bisa Baca Al Qur'an bagi siswa dan calon pengantin.

\footnotetext{
${ }^{32}$ https://www.bbc.com/indonesia/indonesia-39033 231\#share-tools,diakses tanggal 21/11/2018, 23.01
} WIB.
2 Perda Provinsi Sumatera Selatan No. 13/2002 tentang Pemberantasan Maksiat

3 Perda kota Bengkulu No. 24 tahun 2000 tentang Larangan Pelacuran dalam Kota Bengkulu.

4 Perda Pemerintahan kota Tangerang tentang Pelarangan Pelacuran nomor 8 Tahun 2005. dan Perda tentang Pelarangan Pengedaran dan Penjualan Minuman beralkohol dalam Perda No.7/2005.

5 Perda Kabupaten Sukabumi tentang Penertiban Minuman Beralkohol yang diatur dalam Perda No. 11/2005

6 Kota Malang dalam Perda No. 8 Tahun 2005 Tentang Larangan Tempat Pelacuran dan perbuatan Cabul

7 Perda syariah tentang pengelolaan zakat, infaq, dan shadaqoh dalam Perda No. 4/2006

8 Perda Kabupaten Bantul tentang larangan pelacuran dalam Perda No. 5 tahun 2007

9 Perda Provinsi Sumbar No. 11/2004 tentang Pemberantasan dan Pencegahan Maksiat

10 Bukittinggi; Perda Kab. Bukit Tinggi No. 29/2004 tentang Pengelolaan 


\begin{tabular}{llr}
\hline \multicolumn{4}{l}{ Zakat, Infaq, dan Shadaqoh } \\
\hline 11 & Peraturan $\quad$ Daerah $\quad$ Kabupaten \\
& Lampung Selatan No. 4 Tahun 2004 \\
& Tentang $\quad$ Larangan $\quad$ Pebuatan \\
& Prostitusi, Tuna Susila, dan \\
& Perjudian $\quad$ serta $\quad$ pencegahan \\
& perbuatan masksiat dalam Wilayah \\
& Kabupaten Lampung Selatan \\
\hline 12 & Padang Pariaman; Peraturan daerah \\
Kabupaten Padang Pariaman nomor \\
02 Tahun 2004 Tentang Pencegahan, \\
Penindakan dan Pemberantasan \\
Maksiat
\end{tabular}

13 Banjarmasin; Perda Kab. Banjar No. 4/2004 tentang Khatam Al-Qur'an bagi Peserta Didik pada Pendidikan

Dasar dan Menengah dan lain - lain.

Diskriminasi dan intoleransi yang ditujukan pada Perda Bernuansa Syariah yang banyak tumbuh dan berkembang di Indonesia sangatlah tidak beralasan karena bentuk dikriminiasi dan intoleransi tidak kita temukan pada perda - perda bernuansa syariah tersebut. Sebagai contoh perda kabupaten Bengkulu tengah no 5 tahun 2014 mengenai wajib bisa baca Al Qur'an bagi siswa dan calon pengantin. Pendidikan Baca Al Qur'an adalah pendidikan yang memberikan pengetahuan dan membentuk sikap, kepribadian, dan keterampilan siswa dan calon pengantin dalam memahami dan mengamalkan ajaran yang terkandung dalam Al Qur'an, yang dilaksanakan sekurang-kurangnya melalui 75 mata pelajaran pada semua jalur, jenjang sampai dengan jenjang pendidikan menengah $\operatorname{atas}^{33}$, Kemudian Perda tersebut ditujukan kepada siswa - siswa yang beragama islam yang merupakan peserta didik Sekolah Dasar/MI, SMP/MTs dan SMA/SMK/MA ${ }^{34}$, sedangkan calon pengantin adalah seorang laki-laki atau perempuan yang akan melangsungkan pernikahan bagi yang beragama islam ${ }^{35}$, dengan kata lain perda tersebut hanya berlaku bagi masyarakat Bengkulu Tengah yang beragama islam saja. Sehingga tidak akan ada gesekan antara pemeluk agama yang satu dengan agama lainnya bahkan bisa saling menghormati dan memahami.

Contoh lainnya yaitu Perda Kab. Bukit Tinggi No. 29/2004 tentang Pengelolaan Zakat, Infaq, dan Shadaqoh. Perda ini mengatur mengenai pengelolaan zakat yang pada konsideran menimbangnyapun menyebutkan 10 konsideran meimbang yang antara lain Undang-undang Nomor 38 Tahun 1999 tentang Pengelolaan Zakat,Keputusan Presiden Nomor 49 Tahun 2000 tentang Kedudukan. Tugas, Fungsi, Susunan Organisasi dan Tata Kerja Instansi Vertikal Departemen Agama, sebagaimana telah diubah dengan Keputusan Presiden Republik Indonesia Nomor 85 Tahun

${ }^{33}$ Lihat Pasal 1 mengenai Ketentuan Umum angka 5, Perda Bengkulu Tengah Mengenai Wajib Bisa Baca Al Qur'an bagi siswa dan calon pengantin.

34 Ibid, Pasal 1 Angka 12

35 Ibid, Pasal 1 Angka 13. 
AL-IMARAH: Jurnal Pemerintahan dan Politik Islam Vol. 3, No. 1, 2018

2002,Keputusan Menteri Agama Republik Indonesia Nomor 373 Tahun 2003 tentang Pelaksanaan Undang-undang Nomor 38 Tahun 1999 tentang Pengelolaan Zakat, sehingga secara materil jelas bahwa perda tesebut tidak bertentangan dengan peraturan diatasnya ditambah lagi dengan penjelasan siapa yang wajib membayar zakat adalah Muzakki, orang muslim atau badan yang dimiliki oleh orang muslim yang berkewajiban menunaikan zakat $^{36}$ dan ditegaskan dalam ketentuan umum pada pasal 1 nomor 17 bahwa agama adalah agama islam, sehingga jelas tidak akan merugikan bahkan menyinggung bagi umat agama lainya, karena menunaikan zakat merupakan kewajiban bagi Umat Islam yang mampu dan diperuntukkan bagi mereka yang berhak menerimanya, disamping hasil pengumpulan zakat merupakan sumber dana yang potensial bagi upaya mewujudkan kesejahteraan masyarakat terutama dalam mengentaskan masyarakat dari kemiiskinan dan menghilangkan kesenjangan sosial.

Jadi tidaklah benar bahwa perda syariah ataupun perda bernuansa syariah sudah pasti intoleransi dan diskriminasi karena sudah diatur mengenai ruang lingkupnya, justru perda - perda maupun peraturan perundang undangan lain yang berpotensi akan menimbulkan diskriminasi dan intoleransi kepada seluruh masyarakat indoensia agar

\footnotetext{
${ }^{36}$ Lihat Ketentuan Umum dalam Pasal 1 nomor 15 Perda no 29 Tahun 2004 mengeani Pengelolaan Zakat.
}

dapat dikawal dalam pembentukannya dan pemberlakuannya. Konsep Review yang didapat digunakan dalam menilai apakah suatu perda ataupun peraturan perundang - undangan lain itu diskriminatif ataupun intoleransi sehingga bertentangan dengan peraturan perundang - undangan yang diatasnya. Mekanisme review tersebut bisa melalui judicial review di Mahkamah agung bila terjadi peraturan perundang - undangan dibawah undang - undang bertentangan dengan undang - undang atau melalui judicial review di Mahkamah konstitusi bila UU bertentangan dengan UUD NKRI 1945. selain itu ada konsep Eksekutif Review dan Legislatif Review bila suatu partai politik yang telah masuk kedalam sistem dapat merubah dari pemegang kewenangan untuk mengubahnya.

\section{d) Konstitusionalitas Perda Syariah dan Perda Bernuansa Syariah}

\section{Dalam Pasal 28J ayat (2) UUD NRI} 1945 dinyatakan bahwa dalam menjalankan hak dan kebebasannya, setiap orang wajib tuntuk kepada pembatasan yang ditetapkan dengan undang-undang dengan maksud semata-mata untuk menjamin pengakuan serta penghormatan atas hak dan kebebasan orang lain dan untuk memenuhi tuntutan yang adil sesuai dengan pertimbangan moral, nilai-nilai keagamaan, keamanan dan ketertiban umum dalam suatu masyarakat 
demokratis ${ }^{37}$. Berdasarkan pasal tersebut, salah satu sumber hukum materiil dalam pembatasan dalam menjalankan hak dan kebebasan manusia yang ditetapkan dengan peraturan perundang-undangan dengan maksud semata-mata untuk menjamin pengakuan serta penghormatan atas hak dan kebebasan orang lain dan untuk memenuhi tuntutan yang adil adalah nilai-nilai agama dalam suatu masyarakat demokratis. Dengan demikian, konstitusi secara eksplisit mengakui bahwa agama merupakan salah satu sumber hukum yang tidak boleh dikesampingkan. Dengan demikian, perda syariah maupun perda bernuansa syariah dalam otonomi daerah merupakan hal yang konstitusional.

Pemberlakuan Perda syari'ah dan perda bernuansa syariah dalam otonomi daerah di Indonesia dapat mendukung stercapainya salah satu tujuan negara, yaitu memajukan kesejahteraan umum. Ketika peraturan daerah yang memiliki tuntunan keagamaan tersebut diberlakukan maka secara otomatis penyimpangan-penyimpangan dalam ajaran agama Islam dapat diredam serta masyarakat yang terganggu dengan konflik kepentingan antar umat dapat teratasi. Dalam mewujudkan kesejahteraan umum, upaya

\footnotetext{
37 Pasal 28 J ayat (2) UUD NKRI 1945.
}

menumbuhkan karakter bangsa yang sesuai dengan ajaran-ajaran agama atau kepercayaannya yang digunakan sebagai penjaga bagi setiap insan manusia agar tidak mengalami degradasi moral. Perda syariah dan perda bernuansa syariah dalam otonomi daerah kemudian muncul sebagai solusi diantara masalah-masalah tersebut yang disesuaikan dengan kebutuhan hukum masyarakat setempat dalam kehidupan bermasyarakat berbanggsa dan bernegara. Pemberlakuan perda syariah dan perda bernuansa syariah yang disesuaikan dengan kondisi sosial dan budaya masyarakat masing-masing inilah yang nantinya dapat menunjang tercapainya tujuan tersebut.

Dalam Pasal 18 ayat (2) jo ayat (5) UUD NRI 1945 memberikan pemahaman bahwa pemerintah daerah provinsi, daerah kabupaten dan kota berhak menetapkan peraturan daerah untuk mengatur dan mengurus sendiri urusan pemerintahan menurut asas otonomi dan tugas pembantuan. Dalam melaksanakan haknya tersebut, pembentukan peraturan daerah diwarnai oleh semangat untuk memenuhi kepentingan hukum masyarakat setempat. Oleh karena itu, lahirnya Perda-perda yang bersifat khusus di daerah-daerah termasuk Perda yang bersumber dari nilai-nilai syari'ah, merupakan sebuah bentuk penghormatan terhadap keragaman 
daerah di Indonesia untuk mengakomodir kepentingan hukum masyarakat setempat sebagai sebuah negara yang plural dengan memperhatikan karakteristik masyarakat setempat.

Pasal 29 ayat (1) UUD NRI 1945 menyatakan bahwa Negara berdasar atas Ketuhanan Yang Maha Esa. Hal ini merupakan komitmen negara untuk menjamin tegaknya suatu agama dalam jati diri bangsa. Penegakkan suatu agama sebagai jati diri bangsa terimplementasi dengan penyelenggaraan negara yang dilandasi oleh nilai-nilai ketuhanan. Oleh karena itu, pembentukan perda syariah dalam otonomi daerah bukanlah sesuatu yang inkonstitusional.

Pada hakikatnya, penentangan terhadap pemberlakuan perda syariah dalam otonomi daerah merupakan bentuk pengingkaran terhadap jiwa dari semangat ke-Indonesia-an. Indonesia, yang dibangun melalui pilar Bhinneka Tunggal Ika memiliki makna bahwa Indonesia bercirikan keberagaman dalam kesatuan. Dalam konteks otonomi daerah, setiap daerah memiliki ciri khas dan kebutuhan hukum masing-masing, sehingga daerah yang memiliki mayoritas warga negara beragama Islam haruslah diberikan hak untuk mengembangkan dirinya, mengurus dan mengatur daerahnya sesuai dengan nilai-nilai yang hidup dalam masyarakat setempat asalkan tidak mengganggu dan memaksakan suatu nilai tersebut untuk di dianut oleh yang berlainan agama karena sikap toleransi harus dijunjung tinggi dalam berbangsa dan bernegara.

\section{Penutup}

Berdasarkan uraian yang telah dikemukakan, maka dapat disimpulkan sebagai berikut:

1. Perda merupakan penjelmaan dari legal self sufficiency yang bersifat self government yang diatur dan diurus oleh pemerintah setempat, karena otonomi lebih menitikberatkan aspirasi masyarakat setempat daripada kondisi yang berbeda di daerah.

2. Perbedaan yang siknifikan antara perda syariah yang belaku di Aceh dengan perda bernuansa syariah yang banyak lahir di daerah - daerah otonom di Indonesia yaitu terletak pada norma yang digunakan, bila perda syariah memang mengunakan norma agama sebagai landasannya dan diakomodir kedalam bentuk perda secara keseluruhan baik hukumnya maupun hukumannya ( Kaffah/keseluruhan ) sedangkan Perda Bernuansa Syariah normanya harmonis/tidak kontra produktif dengan norma syariah akan tetapi 
juga menjunjung tinggi norma -

norma hukum yang diberlakukan agar

suatu umat tertentu tidak merasa

terganggu atas kehadiran perda

tersebut melainkan dapat hidup

bersama dan berdampingan.

3. Perda syariah ataupun perda bernuansa syariah tidak dapat dijadikan "Kambing Hitam" dalam intoleransi dan diskriminasi, karena setiap Peraturan perundang undangan berpotensi untuk menimbulkan diskriminasi dan intoleransi maka lihat materi dan formilnya.

4. Konstitusionalitas Perda Syariah dan Perda Bernuansa syariah terdapat dalam Pasal 28J ayat (2) UUD NRI 1945 yang menghargai salah satu sumber hukum materiil adalah pembatasan dalam menjalankan hak dan kebebasan manusia yang ditetapkan dengan peraturan perundang-undangan dengan maksud untuk menjamin pengakuan serta penghormatan atas hak dan kebebasan orang lain dan untuk memenuhi tuntutan yang adil adalah nilai-nilai agama dalam suatu masyarakat demokratis.

\section{Pustaka Acuan}

Djamil, Fathurrahman. Filsafat Hukum Islam; Bagian Pertama, (Jakarta: Logos Wacana Ilmu), Cet. I.

http://peraturan.go.id/perda.html, Diakses tanggal 16/11/2018, Pukul 14.05 WIB.

https://id.wikipedia.org/wiki/Agama_di_Indon esia, diambil Sensus Penduduk 2010. Jakarta, Indonesia: Badan Pusat Statistik, diakses tanggal 21 November 2018, 22.47 WIB.

https://id.wikipedia.org/wiki/Daftar_peraturan _daerah_di_Indonesia_berlandaskan _hukum_agama, Diakses pada tanggal 16/11/2018, 14.23 WIB.

https://www.bbc.com/indonesia/indonesia-390 33231\#share-tools,diakses tanggal 21/11/2018, 23.01 WIB.

https://www.youtube.com/watch?v=exnfgml-z kg, tanggal 16/11/2018, Pukul 15.40 WIB.

Manan, Bagir. Menyongsong Fajar Otonomi Daerah. (Yogyakarta: PSH FH UII, 2002)

Marzuki Wahid, Rumadi. Fiqh Mazhab Negara, Kritik Terhadap Politik Hukum Islam di Indonesia,(Yogyakarta: LKIS, 2001). 
AL-IMARAH: Jurnal Pemerintahan dan Politik Islam

Vol. 3, No. 1, 2018

Perda Bengkulu Tengah Mengenai Wajib Bisa

Baca Al Qur'an bagi siswa dan calon pengantin.

Perda Kabupaten Bukit Tinggi No 29 Tahun

2004 mengenai Pengelolaan Zakat.

Pius A partanto dan M. Dahlan Al-barry, Kamus Ilmiah Populer, (Surabaya: Arkola, 1994).

Qanun Aceh Nomor 7 tahun 2013 tentang Hukum Jinayat.

Rahardjo, Satjipto. Peranan dan Kedudukan Asas-Asas Hukum dalam Kerangka Hukum Nasional, (Makalah) FH, Universitas Indonesia, 2000.

Riyamto, Astim, Filsafat Hukum, (Bandung: YAPEMDO, 2010).

Rosjidi Ranggawidjaja, Pengantar Ilmu Perundang-undangan Indonesia, (Bandung: Penerbit Mandar Maju, 1998)

Rudi M Rizky, Filsafat Hukum Pancasila.

Sarundajang, Arus Balik Kekuasaan Pusat ke Daerah, (Jakarta: Pustaka Sinar Harapan, 1999).

Sinclair, Jhon (Ed). Collins COBUIL English Language Dictionary, Cet. 6, (London: Collins, 1990).

Syarif, Amiroeddin Perundang-undangan,Dasar, Jenis dan Teknik Membuatnya, (Jakarta: Bina Aksara 1987)

Syarifudin, Amir. Ushul Fiqh Jilid I, (Jakarta: Logos Wacana Ilmu, 1997), Cet. I.

Syaukani HR., Menatap Harapan Masa Depan Otonomi Daerah, Kutai, Lembaga Pengembangan Pembedayaan Kutai.

Thaib, Dahlan. Tata Cara Mengaplikasikan Peraturan Perundangundangan, (Makalah) FH-Ulf. Yogyakarta, 2003.

Undang - Undang Dasar NKRI 1945.

Wahyono, Padmo. dalam Ronny Sautma Hotma Bako, Pengantar Pembentukan UndangUndang RI. (Bandung: PT. Citra Aditya Bakti,1991.)

William L. Reece, Dictionary of Philosophy and Religion: Eastern and Western Though, Exponded Edition, (New York: Humanity Books, 1996), h. 54, Kamus Besar Bahasa Indonesia, Cet. I (Jakarta: Balai Pustakan, 1998). 